ISSN 1678-3921

Journal homepage: www.embrapa.br/pab

For manuscript submission and journal contents, access: www.scielo.br/pab

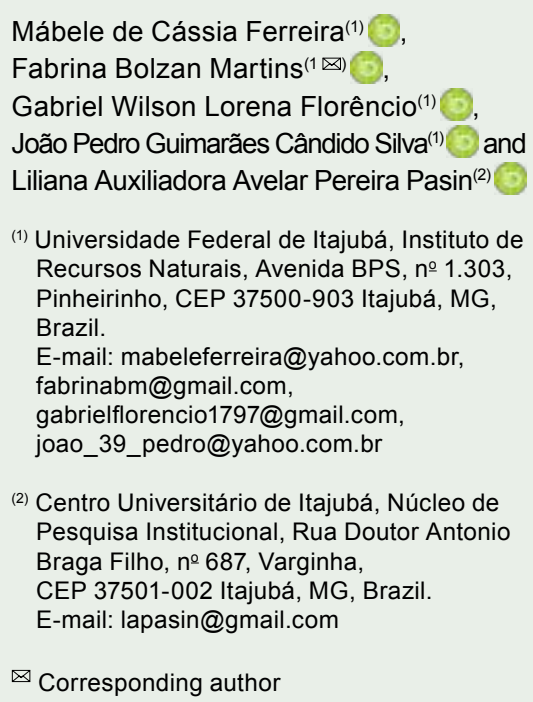

(2) Centro Universitário de Itajubá, Núcleo de Pesquisa Institucional, Rua Doutor Antonio Braga Filho, no 687, Varginha, CEP 37501-002 Itajubá, MG, Brazil. E-mail: lapasin@gmail.com

$\bowtie$ Corresponding author

Received

February 6, 2018

Accepted

June 10, 2019

How to cite FERREIRA, M. de C.; MARTINS, F.B.; FLORÊNCIO, G.W.L.; SILVA, J.P.G.C.; PASIN, L.A.A.P. Cardinal temperatures and thermal requirements for the initial development of two Brazilian native species. Pesquisa Agropecuária Brasileira, v.54, e00525, 2019. DOI: https://doi.org/10.1590/S1678-3921. pab2019.v54.00525.

\section{Cardinal temperatures and thermal requirements for the initial development of two Brazilian native species} \begin{abstract}
appearance, phenology.
\section{Temperaturas cardinais e necessidade térmica para o desenvolvimento inicial de duas espécies nativas brasileiras}

Abstract - The objective of this work was to estimate the cardinal temperatures and to quantify the thermal requirements for the initial development of seedlings of the native tree species Citharexylum myrianthum and Bixa orellana. A field experiment was carried out in a completely randomized design, in a $2 \times 12$ factorial arrangement ( 2 tree species and 12 sowing dates), with five replicates. The base, optimum, and maximum temperatures for the development of $C$. myrianthum were $11.4,18.1$, and $36.6^{\circ} \mathrm{C}$, and, for B. orellana, $12.0,18.4$, and $46.4^{\circ} \mathrm{C}$. The thermal requirements for the development of $C$. myrianthum was $66.7^{\circ} \mathrm{C}$ day per leaf, and, for $B$. orellana, $82.5^{\circ} \mathrm{C}$ day per leaf. In the initial development, $B$. orellana shows a large thermal amplitude and is tolerant to extreme temperatures, while $C$. myrianthum shows a large thermal amplitude, but a lower thermal requirement and a more rapid development than $B$. orellana.

Index terms: Bixa orellana, Citharexylum myrianthum, air temperature, leaf

\begin{abstract}
Resumo - O objetivo deste trabalho foi estimar as temperaturas cardinais e quantificar a necessidade térmica para o desenvolvimento inicial de mudas das espécies de árvores nativas Citharexylum myrianthum e Bixa orellana. $\mathrm{O}$ experimento foi realizado em campo, em delineamento inteiramente casualizado, em arranjo fatorial $2 \times 12$ ( 2 espécies arbóreas e 12 épocas de semeadura), com cinco repetições por tratamento. Os valores de temperatura basal inferior, ótima e basal superior, para o desenvolvimento vegetativo de C. myrianthum, foram $11,4,18,1$ e $36,6^{\circ} \mathrm{C}$, e, para $B$. orellana, $12,0,18,4 \mathrm{e}$ $46,4^{\circ} \mathrm{C}$. A necessidade térmica para o desenvolvimento de $C$. myrianthum foi de $66,69^{\circ} \mathrm{C}$ dia por folha, e, para o de $B$. orellana, de $82,49^{\circ} \mathrm{C}$ dia por folha. $\mathrm{Na}$ fase inicial do desenvolvimento, $B$. orellana apresenta grande amplitude térmica e é tolerante a temperaturas extremas, enquanto $C$. myrianthum apresenta grande amplitude térmica, porém menor necessidade térmica e desenvolvimento mais rápido do que $B$. orellana.
\end{abstract}

Termos para indexação: Bixa orellana, Citharexylum myrianthum, temperatura do ar, emissão de folhas, fenologia.

\section{Introduction}

Air temperature is a main environmental factor that affects the development, vigor, and duration of seedling phase in perennial species 
(Martins et al., 2012; Freitas et al., 2017), influencing the leaf appearance and the permanence period of trees in greenhouses and nurseries (Martins et al., 2007).

The effect of temperature, expressed in degree-days, is determined by the thermal time from which the daily cumulative thermal availability for the species can be computed within certain limits, called the cardinal temperatures (Muttoni et al., 2017). The cardinal temperatures are defined as follows: base temperature, which is considered the temperature below which metabolic processes are reduced, and development is null or diminished; optimum temperature, which is considered the temperature in which the maximum development occurs; maximum temperature, is that above which respiration is greater than photosynthesis, and development is null or diminished (Lisboa et al., 2012; Monteiro et al., 2014; Freitas et al., 2017).

Cardinal temperatures are specific to each species and may vary during the development stage, and according to the cultivars and varieties of the same species (Lago et al., 2009; Farias et al., 2015). The base, optimum, and maximum temperatures are determined by appropriate and distinct statistical methods, and from which phenological data can be counted, such as leaf appearance, for instance. Besides, plants are subjected to different air temperature conditions, as they can be planted in the different sowing dates or in the same sowing date, but in sites with distinct air temperature conditions (Luz et al., 2012; Souza \& Martins, 2014). In some climatic conditions, such as subtropical climate, the convention is to use controlled temperature environments (Muttoni et al., 2017); however, this process is onerous and difficult to put into practice with forest species (Freitas et al., 2017).

Studies on cardinal temperatures are frequently carried out for annual and biannual cultures due to agricultural interest (Lucas et al., 2012; Luz et al., 2012; Gonçalves et al., 2015; Muttoni et al., 2017; Schmidt et al., 2018), but are practically nonexistent for perennial cultures (Souza \& Martins, 2014; Freitas et al., 2017), mainly for tree species native to Brazil. Information on the capacity of a species to adapt to a wide range of environments is of great interest to producers and researchers, since knowledge of cardinal temperatures and thermal requirements values are important for developing and refining optimization strategies to manage and improve both production and its quality, as well as to integrate species that are more adapted to the climactic conditions of cultivation (Martins et al., 2007; Freitas et al., 2017; Schmidt et al., 2018). Furthermore, this information constitutes important input data for forest management models applied to native forest trees, like gap models and mechanistic ones.

Native forest species such as Citharexylum myrianthum Cham. and Bixa orellana L. are important for reforestation programs or for forest preservation. Species like $B$. orellana are also relevant agriculturally and economically due to their seed pigments, which are used in food, pharmaceutical, and cosmetic industries (Ferreira \& Novembre, 2015). However, there is still a great need for studies on the basic cultivation of $C$. myrianthum and B. orellana, as well as on topics related to their temperature limits.

The objective of this work was to estimate the cardinal temperatures and to quantify the thermal requirements for the initial development of seedlings of the native tree species $C$. myrianthum and $B$. orellana.

\section{Materials and Methods}

An experimental field was installed at the Universidade Federal de Itajubá, in the municipality of Itajubá $\left(22^{\circ} 24^{\prime} 46^{\prime \prime} \mathrm{S}, 45^{\circ} 26^{\prime} 49^{\prime \prime} \mathrm{W}\right.$, at $1.050 \mathrm{~m}$ altitude), in the state of Minas Gerais, Brazil. According to the Köppen-Geiger's classification, the climate is a subtropical $\mathrm{Cwa}$, which is characterized by dry winters and hot summers (Abreu et al., 2015). The experiment was carried out in a completely randomized design, in a 2x12 factorial arrangement (two native tree species and twelve sowing dates), with five experimental units per treatment, totaling 120 experimental units. The sowing dates $(\mathrm{Sd})$ were defined in intervals of approximately 30 days (Table 1), so that plants might be exposed to different meteorological conditions (Souza \& Martins, 2014).

Seeds of $C$. myrianthum and $B$. orellana were obtained in two dispersion periods (2015/2016) from plantations located in the municipalities of Piranguinho, São José do Alegre, and Pedralva, all located in the southern Minas Gerais state, Brazil. The collecting, drying, and storing seed, to conserve their viability and to avoid experimental errors, was

Pesq. agropec. bras., Brasília, v.54, e00525, 2019

DOI: 10.1590/S1678-3921.pab2019.v54.00525 
performed according to Lorenzi (2014) and Medeiros (2001).

Each experimental unit contained two plants, cultivated in $8.0 \mathrm{~L}$ containers filled with a moderate type A horizon subsoil, of a Latossolo Vermelho distrófico típico (Santos et al., 2013), i.e. Oxisol, of a class of high-clay content soils, collected in the municipality of Itajubá, in the state of Minas Gerais, Brazil. Considerations and calculations for soil fertility, as well as the covering, followed recommendations set forth in a proposal by the commission for soil fertility of Minas Gerais state (Guimarães et al., 1999). The experimental units were placed upon pallets with $15 \mathrm{~cm}$ spacing, covered with a $30 \%$ shadow-screen positioned at $2 \mathrm{~m}$ above the soil surface. Except for rainy days, the plants were watered regularly (to the point of saturation) in the evening.

The plant development was measured by the number of leaves on the main stem. Counting began as the first leaves emerged, and ended when each experimental unit had 20 leaves on average (Abreu et al., 2015). Leaves were counted weekly, beginning by the emergence of leaves with lengths greater than or equal to $1 \mathrm{~cm}$, disregarding the lateral buds (Souza \& Martins, 2014).

Data from the first four-sowing dates were considered to measure the base temperatures, since they had the lowest-air temperatures. The methodologies used for calculating these temperatures were proposed by Arnold (1959) and Yang et al. (1995), and modifications to these models were proposed by Yang et al. (1995).

Irrespectively of these methods, the degree-days $\left(\mathrm{DD}_{\mathrm{d}},{ }^{\circ} \mathrm{C}\right.$ day) were first gathered, according to Lucas et al. (2012), as follows: $\mathrm{DD}_{\mathrm{d}}=$ Tmed $-\mathrm{Tb} \times$ day, in which: $T_{\text {med }}$ is the medium air temperature, obtained from the arithmetic mean of registries made every 10 min at an automatic weather station $\left({ }^{\circ} \mathrm{C}\right)$; $\mathrm{Tb}$ is the base temperature for each species, from a $\mathrm{Tb}$ series that ranged from 0 to $20^{\circ} \mathrm{C}$, with $0.5^{\circ} \mathrm{C}$ intervals (Lucas et al., 2012).

The accumulated degree-days $\left(\mathrm{DD},{ }^{\circ} \mathrm{C}\right.$ day) were obtained by taking the sum of the $\mathrm{DD}_{\mathrm{d}}$ from the first emergence, in each sowing date, until the end of the seedling phase (Farias et al., 2015). The least standard deviation in degree-days $\left(\mathrm{SD}_{\mathrm{gd}}\right)$, the least standard deviation in days $\left(\mathrm{SD}_{\mathrm{d}}\right)$, the coefficient of variation in days $\left(\mathrm{CV}_{\mathrm{d}}, \%\right)$, the coefficient of variation in degreedays $\left(\mathrm{CV}_{\mathrm{gd}}, \%\right)$, the regression coefficient (RC), and the relative development (RD) were used as methods for estimating the base temperature.

For SDgd, the base temperature for each species is that which results in the lowest standard deviation in growing degree-day among the series of sowing dates (Lago et al., 2009; Souza \& Martins, 2014), as follows:

Table 1. Duration and characterization of air temperature, during the experiment, used to estimate the cardinal temperatures for the initial development stages of Citharexylum myrianthum and Bixa orellana, in the municipality of Itajubá, in the state of Minas Gerais, Brazil.

\begin{tabular}{|c|c|c|c|c|c|c|c|c|c|c|}
\hline \multirow{3}{*}{$\begin{array}{l}\text { Sowing date } \\
\text { (month/day/year) }\end{array}$} & \multicolumn{5}{|c|}{ C. myrianthum } & \multicolumn{5}{|c|}{ B. orellana } \\
\hline & \multirow{2}{*}{$\begin{array}{l}\text { Seedling emergence } \\
\text { (month/day/year) }\end{array}$} & \multirow{2}{*}{$\begin{array}{l}\text { Seedling phase }{ }^{(1)} \\
\text { (days) }\end{array}$} & \multicolumn{3}{|c|}{ Temperature $\left({ }^{\circ} \mathrm{C}\right)^{(2)}$} & \multirow{2}{*}{$\begin{array}{l}\text { Seedling emergence } \\
\text { (month/day/year) }\end{array}$} & \multirow{2}{*}{$\begin{array}{l}\text { Seedling phase }^{(1)} \\
\text { (days) }\end{array}$} & \multicolumn{3}{|c|}{ Temperature $\left({ }^{\circ} \mathrm{C}\right)^{(2)}$} \\
\hline & & & $\mathrm{T}_{\text {med }}$ & $\mathrm{T}_{\max }$ & $\mathrm{T}_{\min }$ & & & $\mathrm{T}_{\mathrm{med}}$ & $\mathrm{T}_{\max }$ & $\mathrm{T}_{\min }$ \\
\hline $\mathrm{Sd} 1,05 / 12 / 2015$ & $06 / 10 / 2015$ & 162 & 19.8 & 27.1 & 14.0 & $06 / 12 / 2015$ & 209 & 20.5 & 27.6 & 15.2 \\
\hline $\mathrm{Sd} 2,06 / 12 / 2015$ & $07 / 15 / 2015$ & 148 & 20.9 & 28.2 & 15.2 & $07 / 10 / 2015$ & 197 & 21.2 & 28.2 & 16.0 \\
\hline $\mathrm{Sd} 3,07 / 10 / 2015$ & $08 / 05 / 2015$ & 141 & 21.7 & 28.9 & 16.2 & $07 / 28 / 2015$ & 184 & 21.7 & 28.7 & 16.4 \\
\hline $\mathrm{Sd} 4,08 / 11 / 2015$ & $09 / 02 / 2015$ & 120 & 22.5 & 29.3 & 17.5 & $08 / 26 / 2015$ & 170 & 22.5 & 29.3 & 17.5 \\
\hline $\mathrm{Sd} 5,09 / 10 / 2015$ & $10 / 05 / 2015$ & 115 & 23.0 & 29.4 & 18.3 & $09 / 30 / 2015$ & 153 & 23.0 & 29.4 & 18.3 \\
\hline Sd6, 10/09/2015 & $11 / 04 / 2015$ & 119 & 22.9 & 29.1 & 18.6 & $10 / 19 / 2015$ & 172 & 22.9 & 29.4 & 18.1 \\
\hline $\mathrm{Sd} 7,11 / 13 / 2015$ & $12 / 08 / 2015$ & 122 & 22.6 & 29.0 & 17.9 & $11 / 27 / 2015$ & 168 & 22.2 & 28.9 & 17.3 \\
\hline $\mathrm{Sd} 8,12 / 11 / 2015$ & $01 / 04 / 2016$ & 130 & 22.0 & 28.7 & 16.8 & $12 / 28 / 2015$ & 144 & 21.8 & 28.5 & 16.8 \\
\hline $\operatorname{Sd} 9,01 / 12 / 2015$ & $02 / 07 / 2016$ & 103 & 21.4 & 28.3 & 16.1 & $01 / 27 / 2016$ & 198 & 19.3 & 27.0 & 13.5 \\
\hline $\operatorname{Sd} 10,02 / 11 / 2016$ & 03/04/2016 & 140 & 18.6 & 26.3 & 12.7 & $02 / 19 / 2016$ & 189 & 18.6 & 26.5 & 12.6 \\
\hline $\mathrm{Sd} 11,03 / 11 / 2016$ & $03 / 31 / 2016$ & 134 & 17.7 & 25.8 & 11.4 & $03 / 24 / 2016$ & 176 & 18.1 & 26.4 & 11.6 \\
\hline $\mathrm{Sd} 12,04 / 12 / 2016$ & 05/05/2016 & 141 & 17.3 & 25.7 & 10.6 & 05/03/2016 & 157 & 17.5 & 26.0 & 10.9 \\
\hline
\end{tabular}

(1)Period from plant emergence, when $50 \%$ of the seedlings were visible above the soil level, until the end of the seedling phase (plants with 20 accumulated leaves, on average, on the main stem. ${ }^{(2)}$ Values obtained from the arithmetic mean of maximum $\left(\mathrm{T}_{\max }\right)$, minimum $\left(\mathrm{T}_{\min }\right)$, and medium $\left(\mathrm{T}_{\mathrm{med}}\right)$ air temperatures. 


$$
\operatorname{SDgd}=\left[\sum_{\mathrm{i}-1}^{\mathrm{n}}(\mathrm{DD}-\mathrm{ADD})^{2} / \mathrm{n}-1\right]^{0.5},
$$

in which: ADD is the average accumulated degrees for all i sowing dates; and $\mathrm{n}$ is the number of sowing dates (which in this study were four).

For SDd, the base temperature in each species is that which results in the lowest standard deviation among sowing dates (Fagundes et al., 2010; Müller et al., 2009): $\mathrm{SD}_{\mathrm{d}}=\mathrm{SD}_{\mathrm{gd}} / \mathrm{T}-\mathrm{Tb}$, in which $\mathrm{T}$ is the average air temperature in all four i sowing dates $\left({ }^{\circ} \mathrm{C}\right)$.

For $\mathrm{CV}_{\mathrm{d}} \%$, the base temperature for each species is that which has the lowest coefficient of variation in days, which is obtained from the relationship of the standard deviation in days with the number of required days to achieve the end of the seedling phase (Lago et al., 2009; Souza \& Martins, 2014):

$$
\mathrm{CV}_{\mathrm{d}}=\left(\mathrm{SD}_{\mathrm{d}} / \overline{\mathrm{x}} \mathrm{d}\right) \times 100
$$

in which: $\bar{x} d$ is the average number of days required to achieve the end of the seedling phase.

For $\mathrm{CV}_{\mathrm{gd}}$, the base temperature for each species is that which has the lowest coefficient of correlation with respect to the degree-days needed to achieve the end of the seedling phase (Souza \& Martins, 2014), as follows: $\mathrm{CV}_{\mathrm{gd}}=\left(\mathrm{SD}_{\mathrm{gd}} / \mathrm{ADD}\right) \times 100$, in which, $\mathrm{ADD}$ is the average accumulated degree-days for all i sowing dates.

For RC, the base temperature for each species is given by the angular coefficient value of the simple linear regression between the DD necessary to achieve the end of the seedling phase and the medium air temperature $\left(\mathrm{T}_{\text {med }},{ }^{\circ} \mathrm{C}\right): \mathrm{DD}=\mathrm{a} \times \mathrm{T}_{\text {med }}+\mathrm{b}$. The angular coefficient for the simple linear regression is positive if the $\mathrm{Tb}$ used to calculate the DD is high; it is negative if $\mathrm{Tb}$ is low; and it is zero (or very close to zero) if $\mathrm{Tb}$ is correct (Fagundes et al., 2010; Souza \& Martins, 2014).

For $\mathrm{RD}$, the base temperature is that which results in a null relative development from the prolongation of the simple linear regression between the RD of the species in function of $\mathrm{T}_{\text {med }}(\mathrm{Tb}=-\mathrm{b} / \mathrm{a})$ (Fagundes et al., 2010; Farias et al., 2015), as follows: $\mathrm{RD}=\mathrm{a} \times \mathrm{T}_{\text {med }}+\mathrm{b}, \mathrm{RD}=100 / \mathrm{N}$, in which: 100 is an arbitrary ordered value; and $\mathrm{N}$ is the number of days to achieve the end of seedling phase in each sowing date.

Modified methods were used (Yang et al., 1995; Lago et al., 2009), as follows:

The least standard deviation in degree-days $\left(\mathrm{SD}_{\mathrm{gd}} \mathrm{mod}\right)$ :

$$
\begin{aligned}
\mathrm{T}_{\mathrm{b}}= & \left(\sum_{\mathrm{i}=1}^{\mathrm{n}} \mathrm{T}_{\text {medi }} \mathrm{di} \sum_{\mathrm{i}=1}^{\mathrm{n}} \mathrm{d}_{\mathrm{i}}-\mathrm{n} \sum_{\mathrm{i}=1}^{\mathrm{n}} \mathrm{d}_{\mathrm{i}}^{2} \mathrm{~T}_{\text {medi }}\right) / \\
& \left\lceil\left(\sum_{\mathrm{i}=1}^{\mathrm{n}} \mathrm{d}_{\mathrm{i}}\right)^{2}-\mathrm{n} \sum_{\mathrm{i}=1}^{\mathrm{n}} \mathrm{d}_{\mathrm{i}}^{2}\right]
\end{aligned}
$$

The least standard deviation in days $\left(\mathrm{SD}_{\mathrm{d} \text { mod }}\right)$ :

$$
\begin{aligned}
& \mathrm{T}_{\mathrm{b}}=\mathrm{T}- {\left[\left(\left(\sum_{\mathrm{i}=1}^{\mathrm{n}} \mathrm{t}_{\mathrm{i}} \mathrm{d}_{\mathrm{i}}\right)^{2}-\mathrm{n} \sum_{\mathrm{i}=1}^{\mathrm{n}} \mathrm{t}_{\mathrm{i}} \mathrm{d}_{\mathrm{i}}{ }^{2}\right) /\right.} \\
&\left.\mathrm{n} \sum_{\mathrm{i}=1}^{\mathrm{n}} \mathrm{d}_{\mathrm{i}}{ }^{2} \mathrm{t}_{\mathrm{i}}-\mathrm{n} \sum_{\mathrm{i}=1}^{\mathrm{n}} \mathrm{t}_{\mathrm{i}} \mathrm{d}_{\mathrm{i}} \sum_{\mathrm{i}=1}^{\mathrm{n}} \mathrm{d}_{\mathrm{i}}\right]
\end{aligned}
$$

The coefficient of variation in degree-days $\left(\mathrm{CV}_{\mathrm{gd} \bmod }\right)$ :

$$
\mathrm{T}_{\mathrm{b}}=\frac{\sum_{\mathrm{i}=1}^{\mathrm{n}} \mathrm{t}_{\text {medi }} \mathrm{d}_{\mathrm{i}}{ }^{2} \sum_{\mathrm{i}=1}^{\mathrm{n}} \mathrm{t}_{\text {medi }} \mathrm{d}_{\mathrm{i}}-\sum_{\mathrm{i}=1}^{\mathrm{n}} \mathrm{d}_{\mathrm{i}} \sum_{\mathrm{i}=1}^{\mathrm{n}} \mathrm{t}_{\text {medi }}{ }^{2} \mathrm{~d}_{\mathrm{i}}{ }^{2}}{\left(\sum_{\mathrm{i}=1}^{\mathrm{n}} \mathrm{d}_{\mathrm{i}}{ }^{2} \sum_{\mathrm{i}=1}^{\mathrm{n}} \mathrm{t}_{\text {medi }} \mathrm{d}_{\mathrm{i}}-\sum_{\mathrm{i}=1}^{\mathrm{n}} \mathrm{d}_{\mathrm{i}} \sum_{\mathrm{i}=1}^{\mathrm{n}} \mathrm{t}_{\text {medi }} \mathrm{d}_{\mathrm{i}}{ }^{2}\right)}
$$

The regression coefficient $\left(\mathrm{RC}_{\text {mod }}\right)$ :

$$
\mathrm{T}_{\mathrm{b}}=\frac{\left(\sum_{\mathrm{i}=1}^{\mathrm{n}} \mathrm{T}_{\text {medi }} \sum_{\mathrm{i}=1}^{\mathrm{n}} \mathrm{d}_{\mathrm{i}} \mathrm{T}_{\text {medi }}-\mathrm{n} \sum_{\mathrm{i}=1}^{\mathrm{n}} \mathrm{d}_{\mathrm{i}} \mathrm{T}_{\text {medi }}^{2}\right)}{\left(\sum_{\mathrm{i}=1}^{\mathrm{n}} \mathrm{d}_{\mathrm{i}} \sum_{\mathrm{i}=1}^{\mathrm{n}} \mathrm{T}_{\text {medi }}-\mathrm{n} \sum_{\mathrm{i}=1}^{\mathrm{n}} \mathrm{d}_{\mathrm{i}} \mathrm{T}_{\text {medi }}\right)}
$$

in which: $d_{i}$ is the duration in days of the $i$ sowing dates; $T_{\text {medi }}$ is the medium air temperature of $\mathrm{i}$ four sowing dates $\left({ }^{\circ} \mathrm{C}\right)$; $\mathrm{T}$ is the average temperature of all $\mathrm{i}$ sowing dates $\left({ }^{\circ} \mathrm{C}\right) ; \mathrm{n}$ is the number of sowing dates; and $\mathrm{t}_{\mathrm{i}}=\mathrm{T}-\mathrm{T}_{\text {medi }}\left({ }^{\circ} \mathrm{C}\right)$.

The final base temperature for the two species was obtained using the arithmetic mean of the values found among the ten estimation methods (equations 2 to 11).

The optimum temperature was estimated (Lisboa et al., 2012; Freitas et al., 2017) by determining the thermal requirements for each species, sowing dates (12), and experimental units. Thermal requirements were obtained by the inverse of the angular coefficient (a) of the simple linear regression between the number of leaves (NL) in the main stem and the accumulated degree-days (DD) counting from the date when leaves first emerged (Table 1) (Martins et al., 2007). To calculate DD was used the base temperature estimated previously: $\mathrm{NL}=\mathrm{a} \times \mathrm{DD}+\mathrm{b}$.

Thermal requirement values were subjected to the normality test of Shapiro-Wilk, at $5 \%$ probability, and to the analysis of variance to test the effects of the variation sources (species and sowing dates). The comparisons were performed using the ScottKnott's test (1974), at 5\% probability. The Tot was obtained using the arithmetic mean of the measured 
air temperatures in the sowing date with the lowest thermal requirement, which was indicated by maximum development (Freitas et al., 2017). All tests were carried out using the Sisvar software 5.3 (Ferreira, 2011).

The maximum temperature (TB) was estimated using the criterion $\mathrm{TB}>\mathrm{T}_{\text {med }}>\mathrm{Tb}$ (Lima \& Silva, 2008), with data from the two sowing dates for the highest-air temperatures (Freitas et al., 2017):

$$
\begin{aligned}
& \mathrm{A}=\mathrm{N}_{2} \times \mathrm{TM}_{1} \times \mathrm{TM}_{2}-\mathrm{N}_{2} \times \mathrm{TM}_{2} \times \mathrm{Tm}_{1}, \\
& \mathrm{~B}=-\mathrm{N}_{1} \times \mathrm{TM}_{1} \times \mathrm{TM}_{2}+\mathrm{N}_{1} \times \mathrm{TM}_{1} \times \mathrm{Tm}_{2} \text {, } \\
& \mathrm{C}=\left(-\mathrm{TM}_{1} \times \mathrm{Tm}_{1}\right) \times\left(-\mathrm{TM}_{2}+\mathrm{Tm}_{2}\right) \text {, } \\
& \mathrm{D}=\mathrm{N}_{1} \times \mathrm{Tm}_{2}^{2} \times \mathrm{N}_{2}-2 \times \mathrm{Tm}_{2} \times \mathrm{N}_{1} \times \mathrm{N}_{2} \\
& \times \mathrm{Tb}-\mathrm{Tm}_{2} \times \mathrm{Tm}_{1} \times \mathrm{N}_{1}{ }^{2}, \\
& \mathrm{E}=-\mathrm{Tm}_{2} \times \mathrm{TM}_{1} \times \mathrm{N}_{1}^{2} \times \mathrm{N}_{2}^{2} \times \mathrm{TM}_{1} \times \mathrm{Tm}_{2} \\
& -\mathrm{Tm}_{1} \times \mathrm{N}_{2}{ }^{2} \times \mathrm{Tm}_{2}+2 \times \mathrm{Tm}_{2} \times \mathrm{N}_{2}{ }^{2} \times \mathrm{Tb}, \\
& \mathrm{F}=\mathrm{Tm}_{1} \times \mathrm{N}_{1}^{2} \times \mathrm{TM}_{2}-2 \times \mathrm{N}_{2}^{2} \times \mathrm{TM}_{1} \times \mathrm{Tb} \\
& -2 \times \mathrm{N}_{1}^{2} \times \mathrm{TM}_{2} \times \mathrm{Tb} \text {, } \\
& \mathrm{G}=\mathrm{TM}_{1} \times \mathrm{N}_{1}^{2} \times \mathrm{TM}_{2}+\mathrm{Tm}_{1}^{2} \times \mathrm{N}_{2} \times \mathrm{N}_{1}-2 \\
& \times \mathrm{Tm}_{1} \times \mathrm{N}_{2} \times \mathrm{N}_{1} \times \mathrm{Tb}, \\
& \mathrm{H}=2 \times \mathrm{Tm}_{1} \times \mathrm{N}_{2}{ }^{2} \times \mathrm{Tb}+2 \times \mathrm{N}_{1} \times \mathrm{TM}_{2} \times \mathrm{N}_{2} \\
& \times \mathrm{Tb}+2 \times \mathrm{N}_{2} \times \mathrm{TM}_{1} \times \mathrm{N}_{1} \times \mathrm{Tb}, \\
& \mathrm{I}=-2 \times \mathrm{N}_{2} \times \mathrm{TM}_{1} \times \mathrm{N}_{1} \times \mathrm{TM}_{2}+\mathrm{N}_{2}^{2} \times \mathrm{TM}_{1} \\
& \times \mathrm{TM}_{2}-\mathrm{Tm}_{1} \times \mathrm{N}_{2}{ }^{2} \times \mathrm{TM}_{2} \text {, } \\
& \mathrm{J}=-\mathrm{N}_{1} \times \mathrm{TM}_{2}+\mathrm{N}_{1} \times \mathrm{Tm}_{2}+\mathrm{N}_{2} \times \mathrm{TM}_{1}-\mathrm{N}_{2} \times \mathrm{Tm}_{1} \text {, } \\
& \mathrm{TB}=(\mathrm{A}+\mathrm{B} \pm \sqrt{\mathrm{C}(\mathrm{D}+\mathrm{E}+\mathrm{F}+\mathrm{G}+\mathrm{H}+\mathrm{I})}) / \mathrm{J},
\end{aligned}
$$

in which: $\mathrm{N}_{1}$ and $\mathrm{N}_{2}$ are the duration of the seedling phase in days, considering a period from $50 \%$ of plant emergence to the end of the seedling phase $(\mathrm{NL}=20)$; $\mathrm{TM}_{1}$ and $\mathrm{TM}_{2}$ are the maximum air temperatures $\left({ }^{\circ} \mathrm{C}\right)$; $\mathrm{Tm}_{1}$ and $\mathrm{Tm}_{2}$ are the minimum air temperatures $\left({ }^{\circ} \mathrm{C}\right)$; subscripts 1 and 2 are the two sowing dates with the greatest medium air temperatures; and $\mathrm{Tb}$ is the base temperature.

\section{Results and Discussion}

The meteorological conditions varied during the entire experimental period (Table 1). Air temperature values varied between $2.3^{\circ} \mathrm{C}$, which is the minimum absolute value observed during sowing dates $\mathrm{Sd} 9, \mathrm{Sd} 10$, $\mathrm{Sd} 11$, and $\mathrm{Sd} 12$, and $35.7^{\circ} \mathrm{C}$, which is the maximum absolute value observed during sowing dates $\mathrm{Sd} 1, \mathrm{Sd}$, $\mathrm{Sd} 3, \mathrm{Sd} 4 \mathrm{Sd}$, and Sd6. These different meteorological conditions are important for estimating cardinal temperatures (Freitas et al., 2017; Lima \& Silva, 2008; Souza \& Martins, 2014).
The different meteorological conditions among the twelve sowing dates influenced the duration (days) of the seedling phase, and it was observed an inverse relationship between the duration of the seasons and the air temperature, that is, the higher the air temperature the lower the duration. The inverse relationship between air temperature and the duration of the seedling phase is expected, and it was also observed in eucalyptus seedlings (Freitas et al., 2017), in canola (Luz et al., 2012), and in the olive cultivars Grappolo and MGS Mariense (Souza \& Martins, 2014).

In general, sowing dates $\mathrm{Sd} 1, \mathrm{Sd} 2, \mathrm{Sd} 3$, and $\mathrm{Sd} 4$ had longer durations and lower-registered air temperatures. This fact justifies choosing these sowing dates (May, June, July, and August) for estimating the base temperature. However, sowing dates Sd5 and Sd6 had higher-registered medium air temperatures (22.9 and $23^{\circ} \mathrm{C}$ ) and were chosen to estimate the maximum temperature, whose conditions are similar to those observed by Freitas et al. (2017).

The base temperature values estimated using the 10 methods (Table 2) had similar results to each other for each species (between 10.9 and $12.1^{\circ} \mathrm{C}$ ). Methods resulting in $\mathrm{Tb} \leq 6.5^{\circ} \mathrm{C}$ were not considered in the base temperature values (Souza \& Martins, 2014), given our field observations and the characteristics of the studied species. Because the methods used for estimating base temperatures are statistical, it is usual to have small differences between statistically estimated

Table 2. Base temperature values $\left(\mathrm{Tb},{ }^{\circ} \mathrm{C}\right)$ for Citharexylum myrianthum and Bixa orellana estimated by the different methods.

\begin{tabular}{lcc}
\hline Method & $\begin{array}{c}\text { C. myrianthum } \\
\left({ }^{\circ} \mathrm{C}\right)\end{array}$ & $\begin{array}{c}\text { B. orellana } \\
\left({ }^{\circ} \mathrm{C}\right)\end{array}$ \\
\hline Least standard deviation in DD & 12 & 12 \\
Least standard deviation in days & 11 & 12 \\
Lowest coefficient of variation in days & 11 & 12 \\
Lowest coefficient of variation in DD & $0^{(1)}$ & 12 \\
Regression coefficient & 11 & 12 \\
Relative development & 11.5 & 12 \\
Least standard deviation in DD - modified & 11.9 & 12.1 \\
Least standard deviation in days - modified & $5.1^{(1)}$ & $6.3^{(1)}$ \\
Least CV in DD - modified & 10.9 & 12 \\
Regression coefficient - modified & 11.2 & 12 \\
\hline Average & 11.4 & 12 \\
\hline (1) Value not used to calculate the Tb average. DD, degree-days. CV, \\
coefficient of variation.
\end{tabular}

Pesq. agropec. bras., Brasília, v.54, e00525, 2019 DOI: 10.1590/S1678-3921.pab2019.v54.00525 
temperatures and the physiological temperature of each species (Lago et al., 2009; Freitas et al., 2017). Therefore, it is important to verify if the estimated base temperatures are within the temperature ranges observed in the field (Schmidt et al., 2018), and coherent with phenological observations. Given this fact, some methods have been shown to register low and unrealistic base temperature, much lower than those registered in the field (Souza \& Martins, 2014); hence, it is customary to exclude values less than or equal to $6.5^{\circ} \mathrm{C}$ for tropical climate species (Lago et al., 2009).

Although the main objective of this work was not to compare the estimation methods, it is worth noting that except for the $\mathrm{SD}_{\mathrm{d} \text { Mod }}$, the other methods were coherent in estimating the base temperature. The efficacy of the methods RC and RD must be highlight. The inefficacy of $\mathrm{SD}_{\mathrm{d} \text { Mod }}$ may be attributed to the fact that this method considers combinations of durations (days in the common calendar) and air temperature. The days of the calendar do not accurately represent the development of seedlings of forest species, and this is still the most frequently used metric for determining when to transplant seedlings in forest nurseries (Martins et al., 2007; Freitas et al., 2017).

The base temperatures estimated for $C$. myrianthum $\left(11.4^{\circ} \mathrm{C}\right)$ and $B$. orellana $\left(12^{\circ} \mathrm{C}\right)$ were coherent with the phenological observations in which no new leaves were observed when air temperature was close to these estimate values. Besides, although these two species show distinct characteristics, they showed estimate values close to those estimated for the vegetative development of perennial species, which also occur naturally in tropical climates, such as Eucalyptus grandis $\left(10^{\circ} \mathrm{C}\right)$ (Martins et al., 2007), Eucalyptus urophylla $\left(11.5^{\circ} \mathrm{C}\right)$ (Freitas et al., 2017) and the coffee cultivars Acaiá Cerrado MG-1474 and Rubi MG-1192 $\left(12.9^{\circ} \mathrm{C}\right)$ (Lima \& Silva, 2008), which were subjected to the same methods as those in the present study, and to others such as the lowest mean square error.

When estimating optimum temperatures, all simple linear regressions had significant angular coefficients and high adjusted coefficients of determination $\left(\mathrm{R}^{2} \mathrm{adj} \geq 0.9822\right.$ for $C$. myrianthum, $\geq 0.9416$ for $B$. orellana), which show that there is a linear relationship between seedling development (given by NL) and the air temperature, shown by DD (Figure 1).
The thermal requirements followed the assumptions of normality according to the Shapiro-Wilk's test, and a significant interaction was observed between the variation sources, species, and sowing dates. The average thermal requirement values for C. myrianthum and B. orellana were $66.69 \pm 7.2$ and $82.49 \pm 6.4^{\circ} \mathrm{C}$ day leaf, respectively (Table 3 ). Thus, $B$. orellana requires more energetic accumulation that C. myrianthum to generate leaves on the main stem. In the field, C. myrianthum developed more quickly than $B$. orellana under relatively similar air temperature conditions (Table 1). Despite this fact, B. orellana showed higher emergence and grew faster and more uniformly at the beginning of the seedling phase.

The thermal requirements were lower on Sd11 and Sd12 and, consequently, the seedling development was greater in these two sowing dates. The optimum temperature estimated was $18.1^{\circ} \mathrm{C}$ for $C$. myrianthum and $18.4^{\circ} \mathrm{C}$ for $B$. orellana. It is worth noting that these values, in theory, are low and inferior to the values found for other forest species, according to Monteiro et al. (2014), who found optimum temperature values of $24.4^{\circ} \mathrm{C}$ for Adenanthera pavonina, $24.9^{\circ} \mathrm{C}$ for Cassia fistula, $24.5^{\circ} \mathrm{C}$ for Hymenolobium petraeum, and $25.1^{\circ} \mathrm{C}$ for Parkia pendula. Nonetheless, in the present study, atypical air temperatures were observed in the period of higher development for the two species, which corresponds to Sd11 and Sd12 (from March to September 2016), with $T_{\text {med }}$ values from 17.2 to $18.1^{\circ} \mathrm{C}$. These values are inferior to the climatic mean values of the studied region, which range from 20.1 to $21^{\circ} \mathrm{C}$ (Reboita et al., 2015). This may have contributed to the lower-estimated optimum temperature values for both species.

As to the maximum temperature, the estimated values were $36.6^{\circ} \mathrm{C}$ for C. myrianthum, and $46.4^{\circ} \mathrm{C}$ for $B$. orellana, which are above the absolute maximum temperature observed during the experimental period $\left(35.7^{\circ} \mathrm{C}\right)$. However, the estimated maximum temperature is expected to be above the maximum air temperature, since this baseline conceptually represents the maximum temperature limit at which the plant would have its metabolic processes inhibited (Freitas et al., 2017; Muttoni et al., 2017).

The maximum temperature estimated for C. myrianthum $\left(36.6^{\circ} \mathrm{C}\right)$ is similar to the values found for other tropical forest species, such as Cassia fistula $\left(37.1^{\circ} \mathrm{C}\right)$ (Monteiro et al., 2014), and Eucalyptus 
grandis $\left(36^{\circ} \mathrm{C}\right)$ and E. saligna $\left(35^{\circ} \mathrm{C}\right)$ (Martins \& Streck, 2007). However, although the maximum temperature $\left(46.4^{\circ} \mathrm{C}\right)$ estimated for $B$. orellana is high, it is justified by the fact that the plant has its origin in a tropical region and is highly adaptable to elevated air temperatures (Ferreira \& Novembre, 2015). The lack of studies of this type makes it practically impossible to compare this species with other forest species of similar nature, especially with respect to the maximum temperature. Despite this, $B$. orellana may be more tolerant and, consequently, more adapted to higher air temperatures than other species, such as: Lippia javanica Spreng., a bush belonging to the Verbenaceae family - the same as that of C. myrianthum -, with a maximum temperature of $37.6^{\circ} \mathrm{C}$ (Mattana et al., 2017); and Corymbia citriodora (Hook.) K.D.Hill \& L.A.S.Johnson, a tree belonging to the Myrtaceae family, with $41.3^{\circ} \mathrm{C}$ (Freitas et al., 2017), which is close to the Cactaceae family, including plants of Polaskia chichipe (Rol.-Goss.) Backeb., with $51.3^{\circ} \mathrm{C}$, and $P$. chende (Rol.-Goss.) A.C.Gibson \& K.E.Horak, with $54.5^{\circ} \mathrm{C}$ (Ordoñez-Salanueva et al., 2015).

With the estimating temperature limits were obtained parameters in which $C$. myrianthum and $B$. orellana can best develop, and identified the thermal requirements under which seedlings should be cultivated to guarantee quality and efficient establishment in the field.
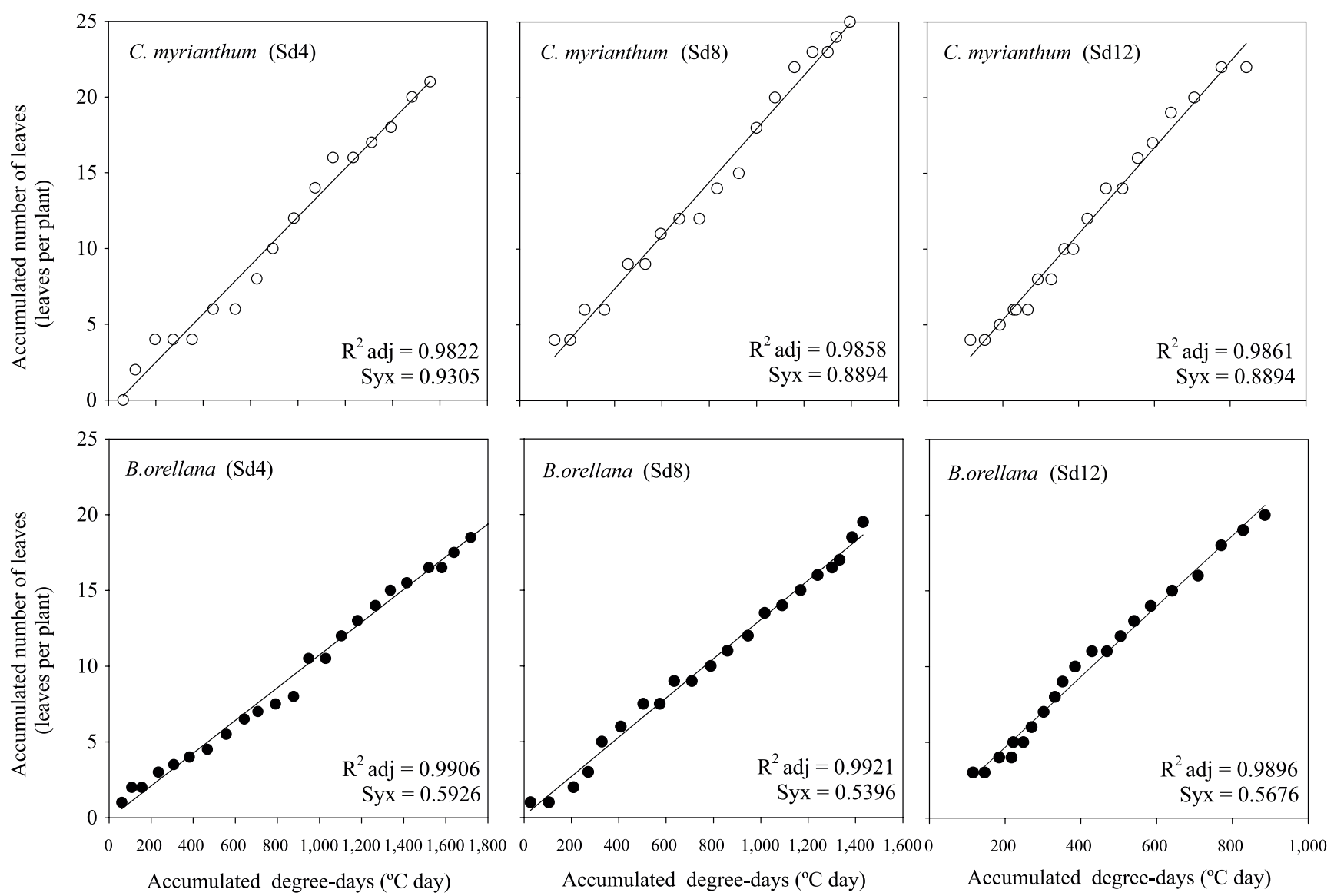

Figure 1. Relationship between the accumulated number of leaves on the main stem and the accumulated degree-days, starting from the date of plant emergence to the end of the seedling phase, using the thermal requirements for estimating Citharexylum myrianthum and Bixa orellana, in three sowing dates (Sd). Data from each sowing date are represented in an experimental unit chosen randomly. $\mathrm{R}^{2}$ adj is the fitted adjusted coefficient of determination, and Syx, the standard estimated error, both are related to the quality of fit of the simple linear regression between the accumulated number of leaves (leaves per plant) and the accumulated degree-days $\left({ }^{\circ} \mathrm{C}\right.$ day). 
Table 3. Mean values for the thermal requirements in degree-days $\left({ }^{\circ} \mathrm{C}\right.$ per leaf) for the twelve sowing dates of Citharexylum myrianthum and Bixa orellana ${ }^{(1)}$.

\begin{tabular}{lcc}
\hline Sowing date & C. myrianthum & B. orellana \\
\hline $\mathrm{Sd} 1$ & $74.18 \mathrm{Ca}$ & $99.01 \mathrm{Db}$ \\
$\mathrm{Sd} 2$ & $74.83 \mathrm{Ca}$ & $100.76 \mathrm{Db}$ \\
$\mathrm{Sd} 3$ & $70.25 \mathrm{Ca}$ & $99.60 \mathrm{Db}$ \\
$\mathrm{Sd} 4$ & $66.30 \mathrm{Ca}$ & $85.84 \mathrm{Cb}$ \\
$\mathrm{Sd} 5$ & $79.10 \mathrm{Da}$ & $102.90 \mathrm{Db}$ \\
$\mathrm{Sd} 6$ & $85.13 \mathrm{Da}$ & $98.06 \mathrm{Da}$ \\
$\mathrm{Sd} 7$ & $82.12 \mathrm{Da}$ & $97.62 \mathrm{Db}$ \\
$\mathrm{Sd} 8$ & $87.95 \mathrm{Da}$ & $76.93 \mathrm{Ca}$ \\
$\mathrm{Sd} 9$ & $57.78 \mathrm{Ba}$ & $76.61 \mathrm{Cb}$ \\
$\mathrm{Sd} 10$ & $48.95 \mathrm{Ba}$ & $68.45 \mathrm{Bb}$ \\
$\mathrm{Sd} 11$ & $36.46 \mathrm{Aa}$ & $46.26 \mathrm{Aa}$ \\
$\mathrm{Sd} 12$ & $37.29 \mathrm{Ab}$ & $41.50 \mathrm{Ab}$ \\
\hline Average & $66.69 \mathrm{a}$ & $82.49 \mathrm{~b}$ \\
\hline
\end{tabular}

${ }^{(1)}$ Means followed by equal letters, uppercases in the columns and lowercases in the lines, do not differ by Scott-Knott's test, at 5\% probability.

\section{Conclusions}

1. Bixa orellana has a large thermal development amplitude and is tolerant to extreme temperatures during its initial development.

2. Citharexylum myrianthum has a large thermal development amplitude; however, it has a lower thermal requirement in its initial development and develops more quickly than $B$. orellana .

3. The estimated cardinal temperature values are necessary as input data in development simulation models, as well as in forest management models for the two native species.

\section{Acknowledgments}

To Coordenação de Aperfeiçoamento de Pessoal de Nível Superior (Capes, process numbers 1489491 and 1827878, finance code 001), for granting scholarships to the $1^{\text {st }}$ and $3^{\text {rd }}$ authors.

\section{References}

ABREU, M.C.; MARTINS, F.B.; FREITAS, C.H. de; PEREIRA, R.A. de A.; MELLONI, E.G.P. Valores limítrofes para transpiração, desenvolvimento e crescimento de Corymbia citriodora (Hook.) K.D. Hill \& L.A.S. Johnson em resposta à deficiência hídrica no solo. Revista Árvore, v.39, p.841-852, 2015. DOI: https://doi.org/10.1590/0100-67622015000500007.
ARNOLD, C.Y. The determination and significance of the base temperature in a linear heat unit system. Proceedings of the American Society for Horticultural Science, v.74, p.430-445, 1959.

FAGUNDES, J.D.; STRECK, N.A.; STORCK, L.; REINIGER, L.R.S. Temperatura-base e soma térmica de subperíodos do desenvolvimento de Aspilia montevidensis. Bragantia, v.69, p.499507,2010.DOI:https://doi.org/10.1590/S0006-87052010000200030.

FARIAS, V.D. da S.; COSTA, D.L.P.; SOUZA, P.J. de O.P de; TAKAKI, A.Y.; LIMA, M.J.A. de. Temperaturas basais e necessidade térmica para o ciclo de desenvolvimento do feijãocaupi. Enciclopédia Biosfera, v.11, p.1781-1792, 2015.

FERREIRA, D.F. Sisvar: a computer statistical analysis system. Ciência e Agrotecnologia, v.35, p.1039-1042, 2011. DOI: https://doi.org/10.1590/S1413-70542011000600001.

FERREIRA, R.L.; NOVEMBRE, A.D. da L.C. Teste de germinação de sementes de urucum (Bixa Orellana L.). Multi-Science Journal, v.1, p.46-52, 2015. DOI: https://doi.org/10.33837/msj.vli3.107.

FREITAS, C.H. de; MARTINS, F.B.; ABREU, M.C. Cardinal temperatures for the leaf development of Corymbia citriodora and Eucalyptus urophylla seedlings. Pesquisa Agropecuária Brasileira, v.52, p.283-292, 2017. DOI: https://doi.org/10.1590/ s0100-204x2017000500001.

GONÇALVES, C.; CASTRO, C.E.F. e; PEDRO JUNIOR, M.J.; TUCCI, M.L.S. Temperature-base and soma thermal for Zinnia 'Profusion Cherry' potted grown in protected environment. Ornamental Horticulture, v.21, p.376-381, 2015. DOI: https://doi.org/10.14295/oh.v21i3.570.

GUIMARÃES, P.T.G.; GARCIA, A.W.R.; ALVAREZ V., V.G.; PREZOTTI, L.C.; VIANA, A.S.; MIGUEL, A.E.; MALAVOLTA, E.; CORRÊA, J.B.; LOPES, A.S.; NOGUEIRA, F.D.; MONTEIRO, A.V.C.; OLIVEIRA, J.A. de. Cafeeiro. In: RIBEIRO, A.C.; GUIMARÃES, P.T.G.; ALVAREZ V., V.H. (Ed.). Recomendações para o uso de corretivos e fertilizantes em Minas Gerais: $5^{\text {a }}$ aproximação. Viçosa: Comissão de Fertilidade do Solo do Estado de Minas Gerais, 1999. p.289-302.

LAGO, I.; STRECK, N.A.; CARVALHO, M.P. de; FAGUNDES, L.K.; PAULA, G.M. de; LOPES, S.J. Estimativa da temperatura base do subperíodo emergência - diferenciação da panícula em arroz cultivado e arroz vermelho. Revista Ceres, v.56, p.288-295, 2009.

LIMA, E.P.; SILVA, E.L. da. Temperatura base, coeficientes de cultura e graus-dia para cafeeiro arábica em fase de implantação. Revista Brasileira de Engenharia Agrícola e Ambiental, v.12, p.266-273, 2008. DOI: https://doi.org/10.1590/S141543662008000300007.

LISBOA, P.M.M.; MARTINS, F.B.; ALVARENGA, M.I.N.; VIEIRA NETO, J.; REIS, D. da F. Desenvolvimento vegetativo de duas cultivares de oliveira na fase de muda. Ciência Rural, v.42, p.1556-1562, 2012. DOI: https://doi.org/10.1590/S010384782012000900007 .

LORENZI, H. Árvores brasileiras: manual de identificação e cultivo de plantas arbóreas nativas do Brasil. 6.ed. Nova Odessa: Instituto Plantarum, 2014. v.1, 384p. 
LUCAS， D.D.P.; STRECK, N.A.; BORTOLUZZI, M.P.; TRENTIN, R.; MALDANER, I.C. Temperatura base para emissão de nós e plastocrono de plantas de melancia. Revista Ciência Agronômica, v.43, p.288-292, 2012. DOI: https://doi.org/10.1590/ S1806-66902012000200011.

LUZ, G.L. da; MEDEIROS, S.L.P.; TOMM, G.O.; BIALOZOR, A.; AMARAL, A.D. do; PIVOTO, D. Temperatura base inferior e ciclo de híbridos de canola. Ciência Rural, v.42, p.1549-1555, 2012. DOI: https://doi.org/10.1590/S0103-84782012000900006.

MARTINS, F.B.; REIS, D. da F.; PINHEIRO, M.V.M. Temperatura base e filocrono em duas cultivares de oliveira. Ciência Rural, v.42, p.1975-1981, 2012. DOI: https://doi.org/10.1590/S010384782012001100011 .

MARTINS, F.B.; SILVA, J.C. da; STRECK, N.A. Estimativa da temperatura-base para emissão de folhas e do filocrono em duas espécies de eucalipto na fase de muda. Revista Árvore, v.31, p.373-381, 2007. DOI: https://doi.org/10.1590/S010067622007000300002 .

MARTINS, F.B.; STRECK, N.A. Aparecimento de folhas em mudas de eucalipto estimado por dois modelos. Pesquisa Agropecuária Brasileira, v.42, p.1091-1100, 2007. DOI: https://oi.org/10.1590/S0100-204X2007000800005.

MATTANA, E.; SACANDE, M.; SANOGO, K.A.; LIRA, R.; GOMEZ-BARREIRO, P.; ROGLEDI, M.; ULIAN, T. Thermal requirements for seed germination of underutilized Lippia species. South African Journal of Biology, v.109, p.223-230, 2017. DOI: https://doi.org/10.1016/j.sajb.2016.12.020.

MEDEIROS, A.C. de S. Armazenamento de sementes de espécies florestais nativas. Colombo: Embrapa Florestas, 2001. 24p. Available at: <https://ainfo.cnptia.embrapa.br/digital/bitstream/ item/17076/1/doc66.PDF>. Accessed on: Jan. 202015.

MONTEIRO, E.B.; DA SILVA, C.C. da; SILVA, A.C. da; SOUZA, A.P. de. Estimating emission of leaves seedlings forest in different shading levels, at conditions of transition Amazon-Cerrado, Brazil. American Journal of Plant Sciences, v.5, p.2330-2341, 2014. DOI: https://doi.org/10.4236/ajps.2014.515247.

MÜLLER, L.; MANFRON, P.A.; MEDEIROS, S.L.P.; STRECK, N.A.; MITTELMMAN, A.; DOURADO NETO, D.; BANDEIRA, A.H.; MORAIS, K.P. Temperatura base inferior e estacionalidade de produção de genótipos diplóides e tetraplóides de azevém. Ciência
Rural, v.39, p.1343-1348, 2009. DOI: https://doi.org/10.1590/S010384782009005000098 .

MUTTONI, M.; ALBERTO, C.M.; BARTZ, A.C.; UHLMAN, L.O.; TARTAGLIA, V. de L.; STRECK, N.A. Cardinal temperatures for planting-emergence phase in gladiolus. Ciência Rural, v.47, e20160824, 2017. DOI: https://doi.org/10.1590/0103$8478 \mathrm{cr} 20160824$.

ORDOÑEZ-SALANUEVA, C.A.; SEAL, C.E.; PRITCHARD, H.W.; OROZCO-SEGOVIA, A.; CANALES-MARTÍNEZ, M.; FLORES-ORTIZ, C.M. Cardinal temperatures and thermal time in Polaskia Backeb (Cactaceae) species: effect of projected soil temperature increase and nurse interaction on germination timing. Journal of Arid Environments, v.115, p.73-80, 2015. DOI: https://doi.org/10.1016/j.jaridenv.2015.01.006

REBOITA, M.S.; RODRIGUES, M.; SILVA, L.F.; ALVES, M.A. Aspectos climáticos do Estado de Minas Gerais. Revista Brasileira de Climatologia, v.17, p.206-226, 2015. DOI: https://doi.org/10.5380/abclima.v17i0.41493.

SANTOS, H.G. dos; JACOMINE, P.K.T.; ANJOS, L.H.C. dos; OLIVEIRA, V.A. de; LUMBRERAS, J.F.; COELHO, M.R.; ALMEIDA, J.A. de; CUNHA, T.J.F.; OLIVEIRA, J.B. de. Sistema brasileiro de classificação de solos. 3.ed. rev. e ampl. Brasília: Embrapa, 2013. 353p.

SCHMIDT, D.; CARON, B.O.; VALERA, O.; MEIRA, D.; FONTANA, D.C.; ZANATTA, T.P.; WERNER, C.J.; BREZOLIN, $\mathrm{P}$. Base temperature, thermal time and phyllochron of escarole cultivation. Horticultura Brasileira, v.36, p.466-472, 2018. DOI: https://doi.org/10.1590/s0102-053620180407.

SCOTT, A.J.; KNOTT, M. A cluster analysis method for grouping means in the analysis of variance. Biometrics, v.30, p.507-512, 1974. DOI: https://doi.org/10.2307/2529204.

SOUZA, P.M.B. de; MARTINS, F.B. Estimativa da temperatura basal inferior para as cultivares de oliveira Grappolo e Maria da Fé. Revista Brasileira de Meteorologia, v.29, p.307-313, 2014. DOI: https://doi.org/10.1590/S0102-77862014000200013.

YANG, S.; LOGAN, J.; COFFEY, D.L. Mathematical formulae for calculating the base temperature for growing degree days. Agricultural and Forest Meteorology, v.74, p.61-74, 1995. DOI: https://doi.org/10.1016/0168-1923(94)02185-M. 